\title{
Os direitos da comunidade e a investigação em saúde
}

\author{
Eunice R. Durham \\ Ruth C.L. Cardoso \\ Maria Carolina Soares Guimarães \\ Frederico Simões Barbosa
}

Preocupada com o uso das comunidades em trabalhos de pesquisa, a Assembléia Geral da Sociedade Brasileira de Medicina Tropical aprovou, em reunião de Assembléia Geral, em Belo Horizonte, no dia seis de março último, a seguinte resolução:

Os países em desenvolvimento são, freqüentemente, campos privilegiados para experiências que envolvem populações. Estes países abrigam também contingentes populacionais importantes que não têm garantidos seus direitos mínimos de cidadania. Nestas circunstâncias, na pesquisa científica que envolva direta ou indiretamente populações humanas, é fundamental que se tomem cuidados especiais para que sejam respeitados em sua plenitude os direitos humanos das populações envolvidas. A necessidade de cuidados especiais é tanto maior quanto mais desinformada estiver a população em relação aos conhecimentos científicos que fazem parte do equipamento do pesquisador e, portanto, menos capaz de se defender de procedimentos potencialmente nocivos ao seu bem-estar coletivo e/ou individual.

Assim:

1. a organização da comunidade é essencial para que possa participar conscientemente, através de suas lideranças e associações, de todo o processo de investigação;

2. a comunidade tem o direito de ser informada sobre a natureza, os objetivos, as vantagens e os eventuais riscos da pesquisa à qual vai ser submetida;

3. ninguém pode ser submetido a um processo experimental sobre o qual não tenha sido previamente informado, e sem a sua expressa anuência;

4. nenhum processo experimental pode ser construído de forma a sonegar à comunidade envolvida medidas preventivas e/ou terapêticas no todo ou em parte;

5. nenhuma comunidade pode ser submetida a experiência (s) que possa (m) implicar o agravamento dos riscos de saúde aos quais está habitualmente submetida;

6. a recusa pela comunidade em se submeter a um dado processo experimental não implicará a privação das ações de saúde às quais esteja habilitada;

Cadernos de Saúde Pública, R.J., 2(2):253-254, abr/jun, 1986 
7. o trabalho comunitário não se deve esgotar com o tér. mino da pesquisa. Seus resultados devem ser traduzidos em informações que sejam úteis à comunidade;

8. os serviços locais de saúde deverão estar informados e, sempre que possivel, devem participar de todo o trabalho;

9. os conhecimentos gerados pela pesquisa devem ser encaminhados ds autoridades de saúde diretamente relacionadas com o tipo de investigação, a fim de que, eventualmente, seus resultados possam ser utilizados pela comunidade.

Para que os direitos da população aqui enunciados sejam observados, é aconselhável:

1. incorporá-los ao Código de Ética Médica, pois, assim, este código além de examinar, julgar ou se necessário, punir a prática médica na sua relação com o doente, individualmente, poderá também legislar quanto às práticas que se estendam às populações;

2. que sejam criadas comissões de ética nas faculdades de Medicipa, Hospitais, Institutos de Pesquisa estatais e particulares para examinar os projetos ali elaborados, do ponto de vista do respeito aos direitos humanos das populações;

3. que sejam criadas nos órgãos financiadores de pesquisas (CNPq, FINEP, FAPESP, etc.) comissões de ética, para examinar os projetos submetidos, sob a ótica do respeito aos direitos humanos das populações. 